\title{
Szintetikus fürdővizek kezelésének és csíranövényekre gyakorolt hatásának elemzése
}

\section{Analysis of the Treatment of Synthetic Bathing Waters and Their Effects on Seedlings}

\author{
Pál Krisztina, ${ }^{1}$ Izbékiné Szabolcsik Andrea, ${ }^{2}$ Bodnár Ildikó, ${ }^{3}$ Bellér Gábor ${ }^{4}$ \\ Debreceni Egyetem, Müszaki Kar, Környezetmérnöki Tanszék, Debrecen, Magyarország \\ ${ }^{1}$ palkrisztina23@gmail.com \\ 2szabolcsikandi@eng.unideb.hu \\ 33bodnari@eng.unideb.hu \\ ${ }^{4}$ beller.gabor@eng.unideb.hu
}

\begin{abstract}
Synthetically produced bathing waters and their effect on seedlings were analysed in our research. The artificially produced bath waters were treated in different ways. Primarily, simple filtration was performed through a layer of silica sand. During the tests, the obtained greywater was investigated before and after the treatment with the help of various water quality parameters. Irrigation was set as the goal of recycling, and germination experiments were performed on mustard seeds. In these experiments, the synthetically generated treated and untreated bath water was used as irrigation water. Considering the results obtained during the germination, it can be said that the treatment is necessary in any case. Based on the results, it was shown that the filtration was not sufficient, so coagulation was used as an additional treatment method, for which we determined the optimal amount of treatment agent as a starting step.
\end{abstract}

Keywords: artificial bathwater, reuse, germination, treatment.

\section{Összefoglalás}

Kutatómunkánk során szintetikusan előállított fürdővizeket és azok csíranövényekre gyakorolt hatását elemeztük. A mesterségesen előállított fürdővizeket különböző módszerekkel kezeltük. Elsősorban egyszerü szürést végeztünk kvarchomokrétegen keresztül. A vizsgálatok során a kapott szürkevizet kezelést megelőzően és azután analizáltuk, különböző vízminőségi paraméterek segítségével. Újrahasznosítási célként az öntözést tűztük ki, ebből adódóan mustármagvakon csíráztatási kísérletet végeztünk el, amelyhez öntözővízként a szintetikus módon létrehozott kezelt és kezeletlen fürdővizet használtuk fel. A csíráztatás során kapott eredményeket tekintve elmondható, hogy a kezelés mindenféleképpen szükséges. A kezelés eredményei nem voltak elégségesek, ezért további kezelési módszerként koagulációt alkalmaztunk, amelyhez kezdő lépésként megállapítottuk az optimális kezelőszer mennyiségét.

Kulcsszavak: szintetikus fürdővíz, újrahasználat, csíráztatás, kezelés.

\section{Bevezetés}

Napjainkban egyre nagyobb globális problémát jelent az édesvíz hiánya, amiből kifolyólag a Föld népességének kb. egyharmada nem jut hozzá a napi ajánlott ivóvízmennyiséghez. A fenntartha- tósági célok alapján kiemelten óvnunk kell a rendelkezésünkre álló ivóvízkészletünket. Azokon a helyeken, ahol már napjainkban is ivóvízhiány lép fel, különböző kezelési módszerek segítségével, pl. a sós tengervízből membrántechnológiai 
megoldásokkal állítanak elő ivóvizet, viszont ezek az eljárások kifejezetten költségesek. Az ivóvízhiány megelőzésére megfelelő módszer lehet pl. az ún. szürkevizek kezelése és újrahasználata.

\section{A szürkevíz}

A háztartási szennyvizek esetében megkülönböztetünk a WC-öblítése során keletkező feketevizet (dark water) és a vizes blokkokban, konyhákban keletkező szürkevizet (greywater), mely utóbbi frakciók nem tartalmaznak fekális eredetű szennyeződéseket. A szürkevizek keletkezhetnek tehát mosás, mosogatás és tisztálkodás során. A mosogatás során keletkező szürkevíz jelentős mértékben tartalmaz ételmaradékokat, zsírokat és a mosogatás során használt mosogatószereket. A mosásból származó vizek nagy koncentrációban tartalmaznak változatos kémiai anyagokat. A tanszéki kutatási, valamint a szakirodalmi adatok alapján a legkevésbé terhelt szürkevízfrakciók egyértelműen a fürdés/zuhanyzás során keletkeznek, amelyek tisztálkodószereket (tusfürdő, sampon, szappan), valamint a bőrfelületről származó zsírokat, olajokat és egyéb szennyeződéseket tartalmaznak [1-3].

A napi egy főre jutó vízfogyasztás Magyarországon jelenleg 100-110 l/fő körül alakul. A vízfogyasztás kb. 38\%-át a tisztálkodás során használjuk fel. Évente a szennyvíztisztító telepekre megközelítőleg 450 millió $\mathrm{m}^{3}$ szennyvíz kerül. Ennek a 38\%-át, közel 171 millió $\mathrm{m}^{3}$ kevésbé terhelt szenynyvíz kezelésével és újrahasználatával jelentős megtakarításra tehetünk szert.

A tisztálkodás során keletkező szennyvizeket kezelés után számos módon újrahasználhatjuk. Ezek közül a két legjellemzőbb felhasználás a WC-k öblítése és az öntözés [4, 5].

A fentiek alapján a kutatásunk alapjául a fürdővizeket választottuk, mint kezelendő és újrahasznosítandó frakció, változatos kezelést alkalmazva újrahasználatként pedig csíranövények segítségével az öntözési megoldást tanulmányoztuk.

\section{Anyag és módszertan}

Vizsgálataink alapját a Debreceni Egyetem Műszaki Karának Környezetmérnöki Tanszék kutatócsoportja által kialakított receptúra által létrehozott szintetikus fürdővíz képezi. A kapott szintetikus fürdővíz vízminőségi paraméterei jól reprezentálják a mindennapok során keletkező fürdővizek tulajdonságait. A fürdővizeket két formában hoztuk létre: hagyományos tisztálkodószerek, illetve ún. öko-tisztálkodószerek mint alkotó összetevők felhasználásával, ezen komponensek ivóvízben történő feloldásával [1, 6, 7]

$\mathrm{Az}$ állandó összetételű, mesterségesen létrehozott fürdővizeket első kísérleti fázisban egyszerű gravitációs szüréssel (1. ábra) kezeltük, amelyhez kvarchomokréteget alkalmaztunk [8].

A folyamatos kezelési hatásfok nyomon követése érdekében vizsgáltuk a létrehozott fürdővizet kezelt és kezeletlen formában, továbbá a fürdővíz alapját képező ivóvizet is analizáltuk. A mérések során a következő vízminőségi paramétereket vizsgáltuk: $\mathrm{pH}$, zéta-potenciál, fajlagos elektromos vezetőképesség, zavarosság, biológiai oxigénigény $\left(\mathrm{BOI}_{5}\right)$, összes szerves széntartalom (T/DOC) és ANA-detergens-tartalom. A pH méréséhez WTW SenTix 41-3 pH-mérő elektródát, a zéta-potenciálhoz, illetve a fajlagos elektromos vezetőképességhez a Zetasizer Nano Z készüléket, a $\mathrm{BOI}_{5}$ esetén OxiTop IS 12 manometrikus BOI-mérő üvegeket, és az összes szerves széntartalom mérésére Shimadzu TOC- $\mathrm{V}_{\mathrm{CPN}}$-típusú készüléket használtunk. Az ANA-detergens-tartalom meghatározására az ISO 2271:1989 szabványt alkalmaztuk [9, 10].

Újrahasználási célként az öntözést tűztük ki, ezért csíráztatási kísérleteket végeztünk fehér mustármagvakon. Öntözővízként a kezeletlen és kezelt szintetikus fürdővizet használtuk, továbbá kontrollvizsgálatként ivóvizes öntözést is végeztünk. A kísérlet mind a hagyományos, mind az ún. öko-tisztálkodószereket tartalmazó fürdővízzel

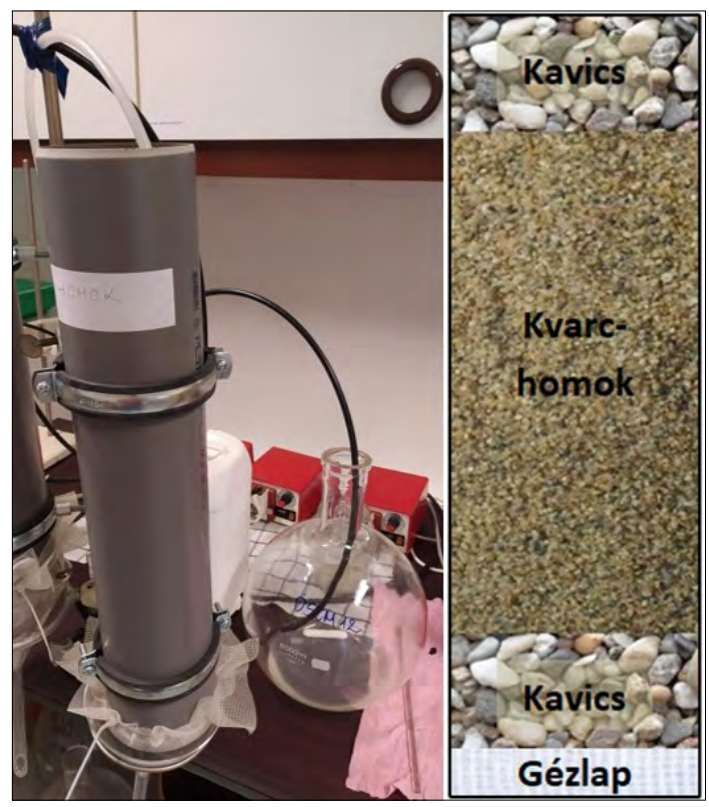

1. ábra. Kvarchomok-szürőközeg 
megtörtént. Aszabvány szerinti csíráztatás 72 órán keresztül történt, amit ezután csíraanalízis követett [11]. A vizsgálat során a következő jellemzőket mértük: kicsírázott magvak száma, gyökér-, illetve szárhossz, nedvességtartalom, nedves-, illetve száraz biomasszatömeg, továbbá a csírák elemanalízise (Agilent ICP-OES-készülékkel) is megtörtént [10].

A kezelés során folyamatosan követtük a vízminőségi jellemzők változását, amelyből megállapítottuk, hogy az első kísérleti fázisban alkalmazott szűrés nem elégséges. Így a továbbiakban kémiai kezelést alkalmaztunk koagulációs kísérletek bevonásával. Első lépésként a zéta-potenciál mérésével megállapítottuk az optimális koagulálószer mennyiségét, ezzel biztosítva a későbbi összetett kezeléseink során optimális kezelőszer-mennyiséget.

\section{Következtetések}

Vizsgálataink alkalmával 2 méréssorozatot végeztünk, mind a hagyományos, mind az öko-tisztálkodószereket tartalmazó fürdővízminták segítségével. A minták analizálása során kapott eredményeket jelen fejezetben ismertetjük.

\subsection{Vízminőségi paraméterek változásai a kezelés hatására}

A kezeletlen szintetikus fürdővíz $\mathrm{pH}$-ja $7,81 \pm 0,03$, míg az ökoszintetikus fürdővízé $8,10 \pm 0,2$ volt. A kvarchomokon történő szürés hatására minimálisan csökkent a pH; a szintetikus minta esetében 7,61 $\pm 0,04-r e$, míg az öko-tisztálkodószereket tartalmazó minták pH-ja 7,73 \pm 0,05-re változott.

A zéta-potenciál mérésekor a szintetikus minta esetében minimális csökkenés következett be a szűrés hatására, (-12,4) $\pm 2,3$ mV-ról (-12.1) \pm 1,6 mV-ra. Ezzel ellentétben az ökoszintetikus minták esetén jelentős csökkenést figyeltünk meg. A kezeletlen minta zéta-potenciálja (-31.4) $\pm 0,4 \mathrm{mV}$ volt, majd a kezelés hatására ez az érték kb. a felére csökkent, és a zéta-potenciál értéke $(-15,6) \pm 1 \mathrm{mV}$ lett.

A minták fajlagos elektromos vezetőképessége mind a két mintacsoport esetén a kezelés eredményeként ugyancsak csökkenést mutatott. A szintetikus minta kezelés előtt átlagosan $897 \pm 0,03 \mu \mathrm{S} / \mathrm{cm}$-t, míg az ökoszintetikus fürdővíz $881 \pm 0,06 \mu \mathrm{S} / \mathrm{cm}-\mathrm{t}$ mutatott. A szürésnek köszönhetően ezek a paraméterek előbbi esetben $754 \pm 0,08 \mu \mathrm{S} / \mathrm{cm}$-re, míg utóbbi esetben $730 \pm 0,1 \mu \mathrm{S} / \mathrm{cm}$-re csökkentek.

A két mintacsoport összes szerves széntartalma (T/DOC) közel megegyezett: a szintetikus mintá- ké átlagosan $72 \pm 1 \mathrm{mg} / \mathrm{l}$ míg az ökoszintetikus mintáké $70 \pm 4 \mathrm{mg} / \mathrm{l}$ volt. A kezelés után is szinte azonos értékre csökkent az összes szerves széntartalom. A szintetikus fürdővizek esetében ez $17 \pm 1 \mathrm{mg} / \mathrm{l}-\mathrm{t}$, az ökoszintetikus fürdővízminták esetén $22 \pm 2 \mathrm{mg} / \mathrm{l}$-t jelentett.

A környezetbe kerülő szennyvizek esetében fontos megemlítenünk a fürdővíz ANA-detergens-tartalmát. A fürdővíz detergenstípusú szennyezői jelentős káros hatással lehet környezetünkre, természetes vízforrásainkra [12]. Az anionakítv detergenstartalom mérése során megállapítottuk, hogy az ökoszintetikus minták detergenstartalma (51 $\pm 1 \mathrm{mg} / \mathrm{l})$ kétszerese a hagyományos tisztálkodószereket tartalmazó vízmintáékénak (22 $\pm 1 \mathrm{mg} / \mathrm{l})$. Szűrést követően méréshatár alatti értéket kaptunk.

A nemzetközi szakirodalmak két vízminőségi paraméter esetén adnak ajánlást a szürkevíz kezelését, illetve újrahasznosítását illetően. Az egyik ilyen paraméter a biológiai oxigénigény $\left(\mathrm{BOI}_{5}\right)$, amely jól reprezentálja a fürdővíz biológiailag bontható szervesanyag-tartalmát. Az ajánlás alapján az újrahasználat feltétele a $10 \mathrm{mg} / \mathrm{l}$ alatti BOI-érték. A szintetikus minták szűrés előtti BOI-értéke $120 \pm 28 \mathrm{mg} / \mathrm{l}$ volt, majd szűrés után ez az érték $60 \pm 1 \mathrm{mg} / \mathrm{l}-\mathrm{re}$, míg az ökoszintetikus fürdővizek esetén $154 \pm 19$ mg/l-ről $75 \pm 16$ mg/l-re csökkent. Megállapítottuk, hogy a fenti ajánlás alapján a minták további kezelést igényelnek.

A másik lényeges vízminőségi jellemző a zavarosság értéke. Az Egyesült Államokban jelenleg hatályban lévő szabályozás szerint az újrahasználatra szánt vizek zavarossága max. 5 NTU, átlagértéke 2 NTU lehet [13]. A kezeletlen minták esetén megállapítottuk, hogy a hagyományos tisztálkodószereket tartalmazó vízminták $(46,7 \pm 2,5$ NTU) zavarossága közel háromszor nagyobb, mint az ökoszintetikus vízmintáké (15,8 \pm 0,1 NTU). Kezelés után a minták zavarossága 2,5 \pm 1,1 NTU-ra, illetve 2,7 \pm 0,6-ra csökkent, azaz az elvárt felső határ alá sikerült csökkentenünk a vízminták zavarosságát, viszont a javasolt 2 NTU-zavarosságiértéket még nem sikerült ezzel a kezeléssel teljesítenünk [7, 14].

\subsection{Csíráztatási kísérletek}

Kutatómunkánkban a kezelést követő újrahasználási célként az öntözést tűztük ki, csíráztatási kísérleteket végeztünk fehér mustármagvakon. Az öntözést kezeletlen és kezelt szintetikus fürdővízmintákkal, illetve ivóvízzel is elvégeztük. Minden öntözővíztípushoz 3-3 Petri-csészét használtunk, melyekbe 25-25 db azonos nagyságú és 
kinézetű mustármagot készítettünk elő (2. ábra). A szabványos kísérlet időtartama 72 óra volt, az öntözés naponta $10 \mathrm{ml}$ vízmintával történt.

A magvakból kinőtt csírákat megvizsgáltuk, a mérési adatok alapján pedig megállapítottuk, hogy öntözést megelőzően a fürdővizet mindenféleképpen szükséges kezelni. Az összehasonlítást az ivóvízzel öntözött csírákhoz viszonyítva végeztük el.

Az 1. táblázat a gyökérrészek hosszát, illetve a gyökérhossz százalékos változását mutatja be. A gyökérhossz a kontrollivóvíz esetén átlagosan $19 \pm 2 \mathrm{~mm}$ és $23 \pm 2 \mathrm{~mm}$ volt. A szintetikus vízminták esetén a kezeletlen fürdővízzel öntözött csírák gyökérhossza a kontrollhoz képest 37,2\%-os csökkenést, míg a kezelt mintáké 14,4\%-os túlnövekedést mutatott.

Az ökoszintetikus vízmintákkal öntözött csírák gyökérhosszával kapcsolatosan megállapítottuk, hogy a szintetikus mintákhoz hasonlóan, a kezeletlen fürdővízzel öntözés a csírák gyökérhosszára 35,5\%-os csökkenéssel bírt, míg a kezelt mintákkal öntözött csírák esetében 7,5\%-os túlfejlődést figyeltünk meg a kontrollivóvízzel öntözött mintákhoz képest.

A 2. táblázat alapján a szárhossz változásait elemeztük. A kontrollivóvízzel öntözött csírák szárhosszai átlagosan 19,0 \pm 1,5 mm és 23,3 $\pm 1,4 \mathrm{~mm}$ voltak. Ehhez az értékhez képest a kezeletlen hagyományos tisztálkodószereket tartalmazó mintákkal öntözött csírák szárhosszai 33,5\%-os, míg az öko-tisztálkodószereket tartalmazó mintákkal öntözött csírák szárhosszai 42,3\%-os csökkenést mutattak. A kezelt minták mind a két mintacsoport esetében túlfejlődést jeleztek, 8,9\%-ot, illetve az ökoszintetikus mintákkal való öntözés esetében 2,4\%-ot.

További vizsgálatainkban a csíraminták nedves, illetve száraz biomasszatömegét és az ebből meghatározható nedvességtartalmat elemeztük. Az alábbi táblázatok a gyökér- és a szárrész nedvességtartalmát szemléltetik.

A gyökérrész esetében (3. táblázat) jelentősebb eltérés a kezeletlen mintákkal történő öntözések esetében figyelhetőek meg. A több mint 10\%-os eltérés azzal a jelenséggel magyarázható, hogy a kezetlen fürdővizekben jelenlévő detergenstartalom eltömíthette a gyökérrész nedvességfelvevő pórusait, így kevesebb nedvességhez jutottak ezek a csírák.

A szárrészek nedvességtartalmai (4. táblázat) közel hasonló eredményeket mutattak a gyökérrészekhez, feltételezhető, hogy ezen minták esetében a gyökérrészből nem jutott elég nedvesség a szárrészbe. Az eltérés ebben az esetben is közel 10\%-os.

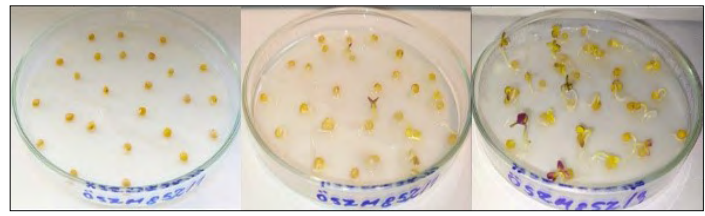

2. ábra. A fehér mustármagcsírák fejlődési folyamatai

1. táblázat. Gyökérrészek hosszára vonatkozó adatok

\begin{tabular}{|l|c|c|c|c|}
\hline \multirow{2}{*}{$\begin{array}{c}\text { GYö- } \\
\text { KÉR }\end{array}$} & $\begin{array}{c}\text { Szinte- } \\
\text { tikus } \\
\text { fürdővíz }\end{array}$ & Változás & $\begin{array}{c}\text { Ökoszin- } \\
\text { tetikus } \\
\text { fürdővíz }\end{array}$ & változás \\
\cline { 2 - 5 } & $\begin{array}{c}\mathbf{m m} \\
\text { Átlag } \pm \text { SD }\end{array}$ & $\%$ & $\begin{array}{c}\mathbf{m m} \\
\text { Átlag } \pm \text { SD }\end{array}$ & $\%$ \\
\hline Ivóvíz & $19,45 \pm 2,36$ & - & $23,43 \pm 1,73$ & - \\
\hline $\begin{array}{l}\text { Kezelet- } \\
\text { len }\end{array}$ & $12,22 \pm 2,16$ & $-37,17$ & $15,12 \pm 1,36$ & $-35,47$ \\
\hline Kezelt & $22,26 \pm 1,72$ & $+14,42$ & $25,18 \pm 0,59$ & $+7,46$ \\
\hline
\end{tabular}

2. táblázat. Szárrészek hosszára vonatkozó adatok

\begin{tabular}{|l|c|c|c|c|}
\hline \multirow{2}{*}{ SZÁR } & $\begin{array}{c}\text { Szinte- } \\
\text { tikus } \\
\text { fürdővíz }\end{array}$ & Változás & $\begin{array}{c}\text { Ökoszin- } \\
\text { tetikus } \\
\text { fürdóvíz }\end{array}$ & Változás \\
\cline { 2 - 5 } & $\begin{array}{c}\text { mm } \\
\text { Álag } \pm \text { SD }\end{array}$ & $\%$ & $\begin{array}{c}\text { mm } \\
\text { Átlag } \pm S D\end{array}$ & $\%$ \\
\hline Ivóvíz & $19,0 \pm 1,5$ & - & $23,3 \pm 1,4$ & - \\
\hline $\begin{array}{l}\text { Kezelet- } \\
\text { len }\end{array}$ & $12,7 \pm 0,3$ & $-33,5$ & $13,5 \pm 0,1$ & $-42,3$ \\
\hline Kezelt & $20,7 \pm 1,2$ & $+8,9$ & $23,9 \pm 1,6$ & $+2,4$ \\
\hline
\end{tabular}

3. táblázat. Gyökérrészek nedvességtartalma

\begin{tabular}{|c|c|c|}
\hline \multirow{2}{*}{ GYöKÉR } & $\begin{array}{c}\text { Szinetikus } \\
\text { fürdővíz }\end{array}$ & $\begin{array}{c}\text { Ökoszintetikus } \\
\text { fürdővíz }\end{array}$ \\
\cline { 2 - 3 } & \multicolumn{2}{|c|}{ Nedvességtartalom } \\
\cline { 2 - 3 } & \multicolumn{2}{|c|}{$\%$ Átlag \pm SD } \\
\hline Ivóvíz & $94,54 \pm 0,29$ & $93,13 \pm 1,91$ \\
\hline Kezeletlen & $85,89 \pm 2,01$ & $85,46 \pm 0,96$ \\
\hline Kezelt & $94,59 \pm 0,79$ & $93,81 \pm 1,33$ \\
\hline
\end{tabular}

4. táblázat. Szárrészek nedvességtartalma

\begin{tabular}{|c|c|c|}
\hline \multirow{2}{*}{ SZÁR } & $\begin{array}{c}\text { Szinetikus } \\
\text { fürdővíz }\end{array}$ & $\begin{array}{c}\text { Ökoszintetikus } \\
\text { fürdővíz }\end{array}$ \\
\cline { 2 - 3 } & \multicolumn{2}{|c|}{ Nedvességtartalom } \\
\cline { 2 - 3 } & \multicolumn{2}{|c|}{ \% Átlag \pm SD } \\
\hline \multirow{2}{*}{ Ivóvíz } & $76,6 \pm 0,7$ & $74,5 \pm 1,8$ \\
\hline Kezeletlen & $66,4 \pm 1,9$ & $63,7 \pm 1,6$ \\
\hline Kezelt & $79,8 \pm 0,2$ & $75,6 \pm 3,1$ \\
\hline
\end{tabular}


A csírákon elemanalitikai vizsgálatokat is végeztünk, abból a célból, hogy feltérképezzük az öntözővíz hatását a mikro-, illetve makroelem-tartalomra.

A mikroelemek (3. ábra) közül a szárrészben jelentős mennyiségben a vas, a cink és a mangán, míg a gyökérrészekben a bór, a réz, a vas és a cink volt azonosítható.

A makroelem-koncentrációkat értékelve (4. ábra) megfigyeltük, hogy a szárrészekben leginkább a kalcium, a kálium és a réz raktározódik el, míg a gyökérrészek esetében nagy koncentrációt mutatott a kalcium, a kálium és a vas.

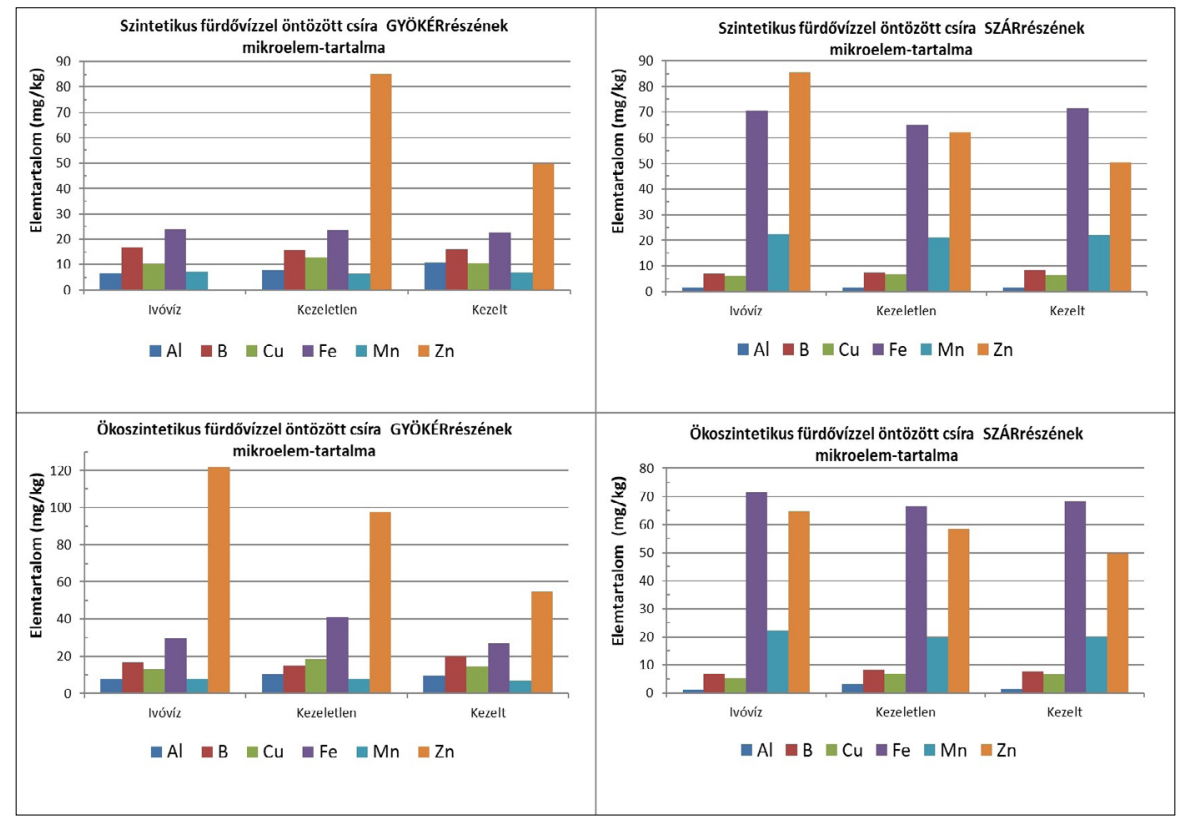

3. ábra. Mikroelemek mennyisége az egyes növényi részekben

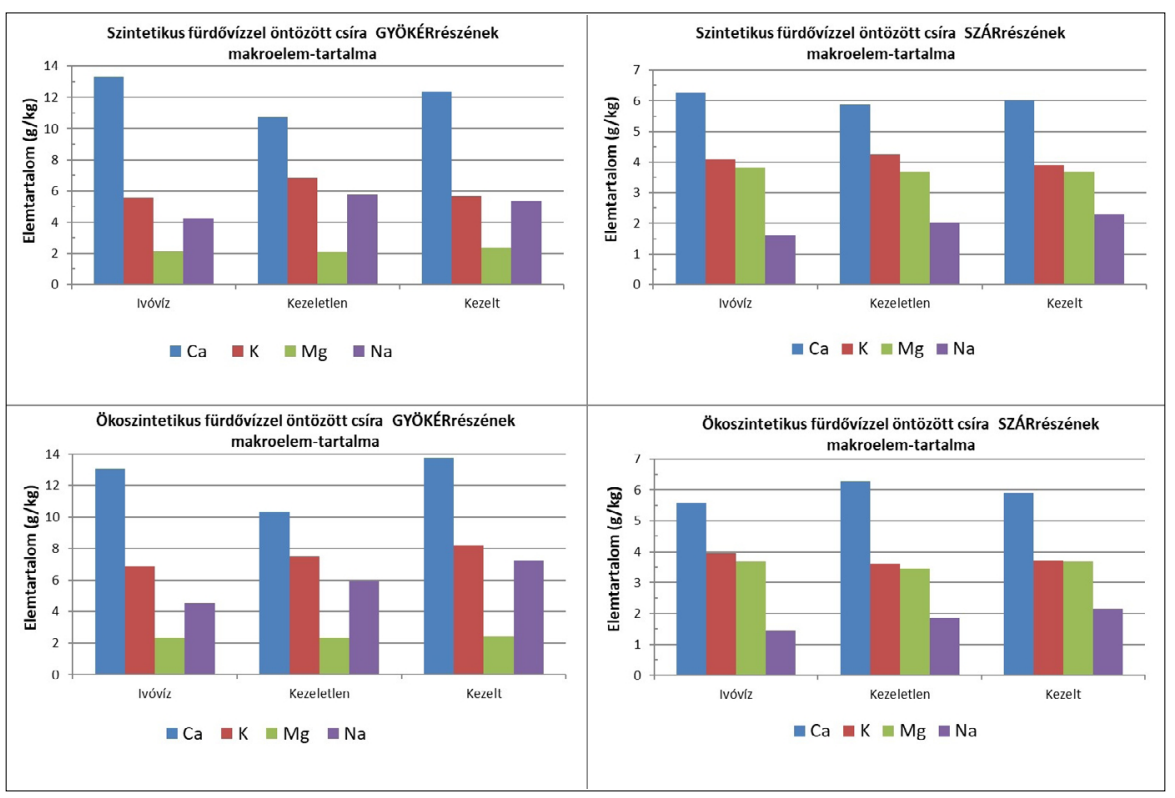

4. ábra. Makroelemek mennyisége az egyes növényi részekben 


\subsection{Koaguláció}

Az kísérleteink kezdetén egyszerű homokszüréssel kezeltük a szintetikus úton előállított fürdővízmintákat. A kezelés hatékonysága a nemzetközi ajánlásokat figyelembe véve nem bizonyult elégségesnek, így vegyszeres kezeléssel terveztük kiegészíteni a szűrési műveletet. Vegyszeres kezelésként vas(III)-kloriddal végzett koagulációt választottuk, amellyel a mintákban található oldott komponensek oldatlan csapadékká alakíthatóak, ülepíthetőek és kiszűrhetőek [15].

Kezdeti lépésként a szükséges koagulálószer optimális mennyiségét határoztuk meg ún. zéta-potenciál-méréssel. A koaguláció abban az esetben nevezhető sikeresnek, ha a kezelt minták zéta-potenciálja $-5 \mathrm{mV}$ és $5 \mathrm{mV}$ közé esik, illetve elérjük az ún. izoelektromos pontnak megfelelő $0 \mathrm{mV}$ zéta-potenciált.

Az eljáráshoz 25 g/l koncentrációjú vas(III)klorid törzsoldatot ( $\mathrm{FeCl}_{3} \times 6 \mathrm{H}_{2} \mathrm{O}$-ból készítve) alkalmaztunk. Az optimális kezelőszer menynyiségének megállapításához koagulációs kísérleteket végeztünk, melynek tapasztalatai a 5. ábrán láthatóak.

A szintetikus fürdővízminták esetén (6. ábra) az optimális koagulálószer mennyisége $-5 \mathrm{mV}$ és $5 \mathrm{mV}$ közötti tartományban minimum $90 \mathrm{mg} / \mathrm{l}$ és maximum 99 mg/l koncentráció értékekben adható meg.

Az ökoszintetikus fürdővízminták (7. ábra) esetén 94-107 mg/ $\mathrm{Fe}^{3+}$-adagolása szükséges.

További kutatómunkánkban a fent ismertetett eredmények alapján 11 helyett 41 mintákon tervezzük a koagulációs kísérleteinket követően homokszüréssel jelentősen javítani a kezelt fürdővíz minőségét. Ez által nagy valószínűséggel tudjuk teljesíteni a nemzetközi ajánlásokban szerepeltetett paraméterek határértékeit. A léptéknövelést követően újabb csíráztatási, esetlegesen fejlettebb növények termesztési kísérleteinek elvégzését tervezzük.

\section{Köszönetnyilvánítás}

Köszönjük Dr. Baranyai Edinának és Sajtos Zsófiának, hogy a kutatómunkánk során segítségünkre voltak a minták elemtartalmának vizsgálatában.

A publikáció és a prezentáció elkészítését az EFOP-3.6.1-16-2016-00022 számú projekt támogatta. A projekt az Európai Unió támogatásával, az Európai Szociális Alap társfinanszírozásával valósult meg.

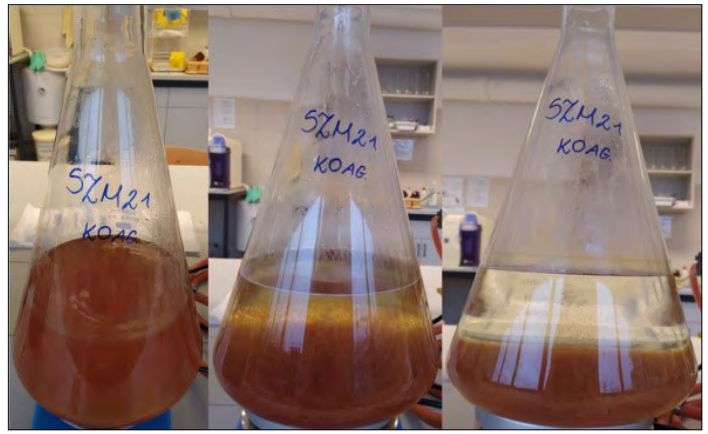

5. ábra. Koaguláció folyamata. A minta a koagulálószer hozzáadása után kevertetve, ülepités közben és ülepités után.

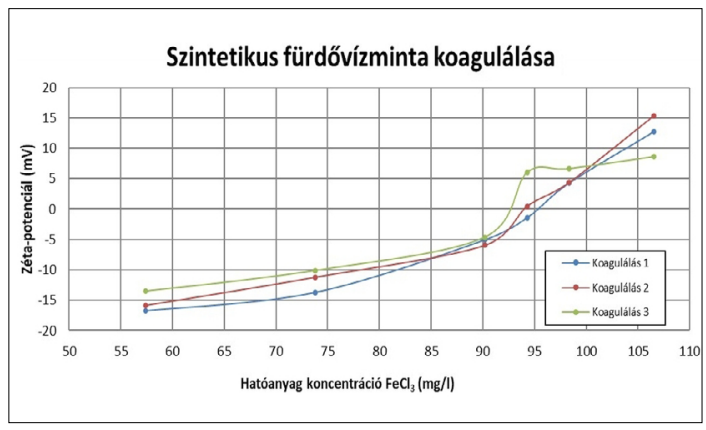

6. ábra. Hagyományos tisztálkodószereket tartalmazó fürdővízminták koagulációja

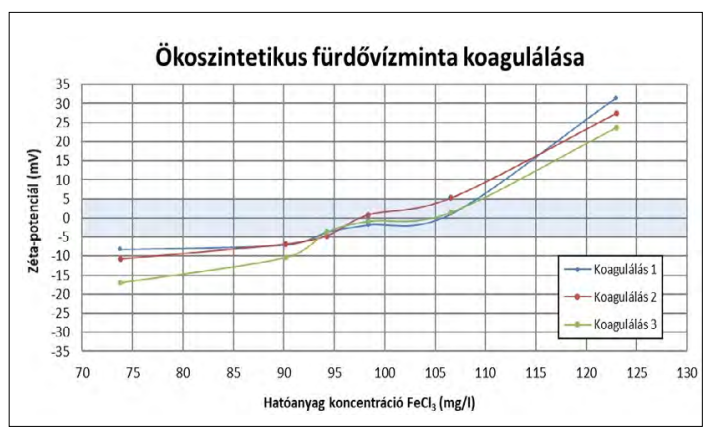

7. ábra. Öko-tisztálkodószereket tartalmazó fürdővízminták koagulációja

\section{Szakirodalmi hivatkozások}

[1] Bodnár I., Boros N., Fehérné Baranyai E., Fórián S., Izbékiné Szabolcsik A., Jolánkai G., Keczánné Üveges A., Kocsis D.: Épületek csapadékvizeinek és szürkevizeinek vizsgálata az Észak-Alföld régióban környezetbarát és energiahatékony hasznosítás céljából. In: Kalmár F. (szerk.): Fenntartható energetika megújuló energiaforrások optimalizált integrálásával. Akadémiai Kiadó, Budapest. 2014. 167-201. 
[2] Allen L., Christian-Smith J., Palaniappan M.: Overview of Greywater Reuse: the Potential of Greywater Systems to Aid Sustainable Water Management. Pacific Institute, 654/1. (2010) 19-21.

[3] Bilson S.: How Greywater Systems Work. ProQuest, 1998.

[4] Winward G. P., Avery L. M., Frazer-Williams R., Pidou,M., Jeffrey P., Stephenson T., Jefferson B.: A Study of the Microbial Quality of Grey Water and an Evaluation of Treatment Technologies for Reuse. Ecological Engineering, 32/2. (2008) 187-190.

[5] Barker-Reid F., Harper G. A., Hamilton A. J.: Affluent Effluent: Growing Vegetables with Wastewater in Melbourne, Australia-a Wealthy but BoneDry City. Irrigation and Drainage Systems, 24/1. (2010) 79-94.

[6] Bodnar I., Szabolcsik A., Baranyai E., Uveges A., Boros N.: Qualitative Characterization of the Household Greywater in Northern Great Plain Region of Hungary. Environmental Engineering and Management Journal, 13/11. (2014) 2717-2724. https://doi.org/10.30638/eemj.2014.302

[7] Szabolcsik A., Baranyai E. Bodnár I.: Utilization of Modern Analytical Techniques for the Analysis of House-Hold Generated Greywater Samples. International Review Of Applied Sciences And Engineering, 6/1. (2015) 53-59.

[8] Dubey A. K., Sahu O.: Review on Natural Methods for Waste Water Treatment. Journal of Urban and Environmental Engineering, 8/1. (2014) 89-97. https://www.redalyc.org/articulo.oa?id=2832324 12009
[9] Ghaitidak D. M., Yadav K. D.: Characteristics and Treatment of Greywater - a Review. Environmental Science and Pollution Research, 20/5. (2013) 2795-2809.

https://doi.org/10.1007/s11356-013-1533-0

[10] Finley S., Barrington S., Lyew D.: Reuse of Domestic Greywater for the Irrigation of Food Crops. Water, Air, and Soil Pollution, 199/1. (2009) 235-245. https://doi.org/10.1007/s11270-008-9874-x

[11] MSZ 22902-4: Víztoxikológiai vizsgálatok, 1990.

[12] Bhairi S. M., Mohan C.: Detergents: A Guide to the Properties and Uses of Detergents in Biology and Biochemistry. EMD Biosciences, SanDiego, CA, 2007.

[13] USEPA (United States Environmental Protection Agency), Guidelines for Water Reuse. Report EPA/625/R-04/108, USEPA, Washington, DC, USA. 2004.

[14] Oron G., Adel M., Agmon V., Friedler E., Halperin R., Leshem E., Weinberg D.: Greywater Use in Israel and Worldwide: Standards and Prospects. Water Research, 58, (2014) 92-101. https://doi.org/10.1016/j.watres.2014.03.032

[15] Ghaitidak D. M., Yadav K. D.: Reuse of Greywater: Effect of Coagulant. Desalination and Water Treatment, 54/9. (2015) 913-925. https://doi.org/10.1080/19443994.2014.924036 